\title{
The effect of opening an ice-rink on the accident and emergency department of a district general hospital
}

\author{
M. V. PRESCOTT \\ Department of Accident and Emergency Medicine, Royal Shrewsbury Hospital (North), \\ Shrewsbury, Shropshire, England
}

\section{INTRODUCTION}

In October 1984, an ice-rink was opened in Telford. There had not been such a facility in the County before. The opening of this leisure facility has created an additional demand on the emergency services of the serving District General Hospital at a time of extreme financial hardship. This is a survey of the first 186 patients from the ice-rink who attended the Accident and Emergency (A \& E) Department of the Royal Shrewsbury Hospital. Injuries were in three main groups: those of instability, those resulting from a fall onto the ice and those occurring after the fall. The majority were soft-tissue damage ( $71 \%$ ), but $27 \%$ were fractures. The cost to the Health Authority of these attendances from this new source of leisure have been calculated at $£ 11296$ (April 1985). The department will see 550 patients from the ice-rink in a year at an estimated cost of $£ 30915$ to the District Health Authority.

\section{METHODS}

The A \& E Department of the Royal Shrewsbury Hospital sees 26000 new patients per year. It is staffed by a single Consultant and four Senior House Officers. Back-up facilities are provided by a 630 -bedded District General Hospital. These include Trauma (Orthopaedic) and General Surgical in-patient services.

When an ice-rink opened in the adjoining town of Telford in October 1984 it became apparent in the first week that this was to become a regular source of patients. A study was initiated, attempting to identify patients from that site. Records of patients who attended from there were kept. The information obtained included numbers presenting

Correspondence: $\mathrm{Mr}$ M. V. Prescott, Consultant in Accident and Emergency Medicine, Royal Shrewsbury Hospital (North), Mytton Oak Road, Shrewsbury, Shropshire, England 
per week throughout the study, the age and sex of the patients, their mode of referral $\stackrel{\mathrm{F}}{\mathrm{B}}$ and transport, and the sites and type of injury. Whether the patient was $\mathrm{x}$-rayed or not, $\stackrel{0}{0}$ the treatment given and disposal of the patient were noted.

Based on this survey, an estimate of the annual cost to the National Health Service of $\stackrel{\circ}{\circ}$ this new source of referral has been made.

\section{RESULTS}

The first 200 attenders were recorded, presenting between 24 October 1984 and 25. March 1985 and averaging 10.5 per week, of which 186 records were traced. $\vec{\omega}$ Ninety-eight were female, 88 male. Their age ranged from 2 to 60 years (Fig. 1).

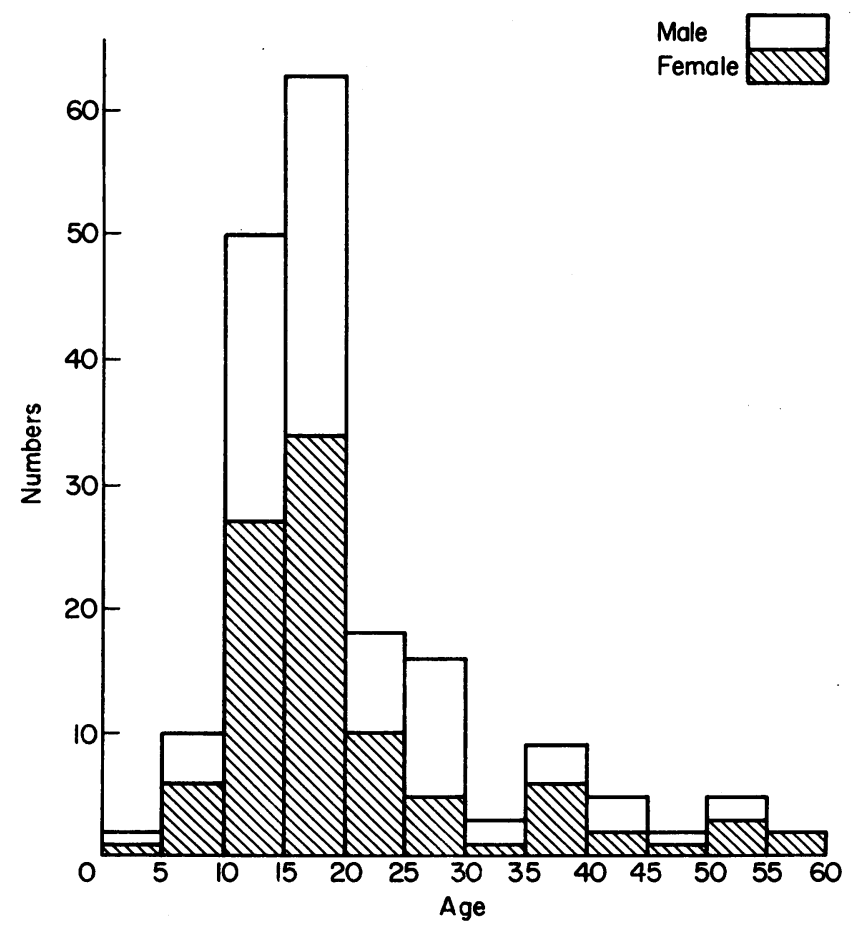

Fig. 1 Age and sex distribution of injured.

Ninety-four (50.5\%) attended the Department between 9am and 5pm; 92 (49.5\%) between $5 \mathrm{pm}$ and $9 \mathrm{am}$. Sixty patients arrived by Ambulance ( 37 of these were carried after 5pm), 118 used a car and eight managed Public Transport.

One hundred and fifty-four (82.8\%) attended the A \& E Department as the first site of medical aid, only $32(17.2 \%)$ seeing their general practitioner first. One hundred and sixty-five patients were $\mathrm{X}$-rayed. 
- One hundred and eighty-six patients had 199 injuries:
Soft tissue injuries
Dislocations
$142(71 \cdot 4 \%)$
$3(1.5 \%)$
Fractures
$54(27 \cdot 1 \%)$

Treatment for the 186 patients was as follows:

No treatment

Simple dressing

Plaster-of-Paris

Local anaesthetic suturing

and joint aspiration

G.A. or regional block
$46(24 \cdot 7 \%)$

$74(39.8 \%)$

$42(22 \cdot 6 \%)$

$8(4 \cdot 3 \%)$

$12(6.5 \%)$

Patients were discharged from the department as follows:

No follow-up

G.P. follow-up

Hospital O.P.D.

Admitted

$$
\begin{aligned}
& 78(41.9 \%) \\
& 18(9.7 \%) \\
& 78(41.9 \%) \\
& 12(6.45 \%)
\end{aligned}
$$

The cost to the District Health Authority was estimated by the Treasurer's Office who were asked to calculate the expense of the management of these 186 patients, including transport. This was $£ 11296$, comprising basic $A \& E$ care $(£ 16.38$ per unit), Ambulance journeys ( $£ 1.40$ per mile), clinic attendance ( $£ 21.79$ per unit), X-ray costs as averaged on wrists and ankles and admissions $(£ 73.00$ per patient/day).

In the 19 weeks of the study 200 patients were seen, averaging 10.5 per week, and, projected, this means that the department can expect to see nearly 550 patients per year at a present-day cost of $£ 30915$.

Table 1 Site and classification of injuries, 197 injuries in 186 patients

\begin{tabular}{lccccc}
\hline Site & Total & Fracture & Dislocation & $\begin{array}{c}\text { Soft-tissue } \\
\text { injury }\end{array}$ & Admitted \\
\hline Wrist & 50 & 28 & 0 & 22 & 0 \\
Knee & 28 & 1 & 2 & 25 & 1 \\
Ankle & 27 & 8 & 0 & 19 & 2 \\
Skull & 21 & 2 & 0 & 19 & 6 \\
Hand & 19 & 6 & 1 & 12 & 0 \\
Elbow & 12 & 3 & 0 & 9 & 0 \\
Shoulder & 9 & 1 & 0 & 3 & 0 \\
Face & 7 & 1 & 0 & 6 & 0 \\
Tib./Fib. & 5 & 3 & 0 & 2 & 3 \\
Lum. Spine & 5 & 1 & 0 & 4 & 0 \\
Hip & 5 & 0 & 0 & 5 & 0 \\
Neck & 3 & 0 & 0 & 3 & 0 \\
Chest & 3 & 0 & 0 & 3 & 0 \\
Forearm & 2 & 0 & 0 & 2 & 0 \\
Pelvis & 2 & 0 & 0 & 2 & 0 \\
Foot & 1 & 0 & 0 & 1 & 0 \\
\hline
\end{tabular}




\section{DISCUSSION}

The injuries presented in this study can be classified in three main groups:

- those sustained at the time of, and as a direct result of, imbalance $(18.6 \%)$. These were inversion/eversion injuries to the ankle (27) and rotational injuries to the leg

(three to the tibia and fibular and seven to the knee);
the result of impact with the ice or the surrounding barrier (79.6\%), 38 being $\frac{\bar{\sigma}}{\overline{5}}$. fractures of the upper limb; and

- injuries occurring after the fall, when the patient was down on the ice, causing by the skate of another person (the run-over injury to the outstretched limb), 12 occurring ${ }^{\infty}$ to the hand and two to the forearm. These resulted in mainly soft-tissue injuries, although two patients had associated fractures communicating with digital lacerations.

Studies of ice-rink injuries have been reported previously. Beiner \& Muller (1973) $\stackrel{\mathbb{9}}{3}$ presented a large study of ice-skaters alone, whilst Horner \& McCabe (1984) compared $\underset{\sim}{\dot{\omega}}$ ice-skate injuries with these from roller-disco in Dublin. Biener \& Muller showed that $\overrightarrow{-}$ the greatest number of injuries occurred in males of the 10- to 19-year-old group. The mean age $(20.9)$ in the study reported here is similar to that reported by Horner $\&$ ?

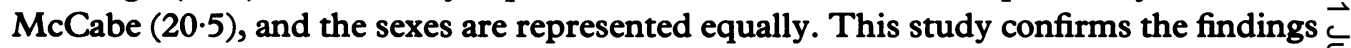
of the other authors that fractures and soft-tissue injuries are a common hazard for ice skaters.

This particular ice-rink was staffed by trained first aiders, but their presence can onky $\stackrel{\circ}{\circ}$ influence the outcome of an injury, not its occurrence. Some of the injuries might have been prevented by protective clothing. However, if people skate they will receive injuries, and a financial cost to the community will ensue.

Perhaps the future development of leisure activites should be accompanied by a simultaneous increase in the money available to the group that has to cope with the consequences. This could come from various sources such as the local council who develop the resource, the National Health Service Central funds or an insurance scheme linked to the entrance fee of the facility.

\section{REFERENCES}

Biener V. K. \& Muller P. (1973) Eislaufunfälle-Epidemologie und Prevention. Forschritte der Medizin 91, $185-6$.

Horner \& McCabe (1984) Ice-Skating and Roller Disco Injuries in Dublin. British fournal of Sports Medicine 18, 207-11. 